\title{
Water productivity assessments for dwarf coconut by using Landsat 8 images and agrometeorological data
}

\author{
A.H. de C. Teixeira ${ }^{a}{ }^{*}$, F.R. de Miranda ${ }^{b}$, J.F. Leivas ${ }^{c}$, E.P. Pacheco ${ }^{d}$, E.A.M. Garçon ${ }^{c}$

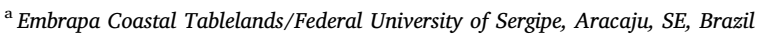 \\ ${ }^{\mathrm{b}}$ Embrapa Agroindustry, Fortaleza, CE, Brazil \\ ${ }^{\mathrm{c}}$ Embrapa Territory, Campinas, SP, Brazil \\ ${ }^{\mathrm{d}}$ Embrapa Coastal Tablelands, Aracaju, SE, Brazil
}

\section{A R T I C L E I N F O}

\section{Keywords:}

Evapotranspiration

Biomass production

Irrigation management

Remote sensing

Cocos nucifera L.

\begin{abstract}
A B S T R A C T
In the coastal areas of Northeast Brazil, coconut growers are replacing the tall varieties by the dwarf ones, following incentives for the coconut's water market. The current study aimed to determine and analyze actual evapotranspiration (ET) and biomass production (BIO), for dwarf coconut water productivity (WP) assessments. This was done to subsidize the rational irrigation and crop management, by using Landsat 8 images together with agrometeorological data during the year 2016 in the Camocim County, coastal zone of Ceará state. The SAFER (Simple Algorithm for Evapotranspiration Retrieving) algorithm was used to retrieve ET, while for BIO estimations we applied the Monteith's radiation use efficiency model (RUE), then the water productivity based on ET was calculated $\left(\mathrm{WP}_{\mathrm{ET}}=\mathrm{BIO} / \mathrm{ET}\right)$. The highest ET and BIO rates, above $4.0 \pm 0.6 \mathrm{~mm} \mathrm{~d}^{-1}$ and $140 \pm 37 \mathrm{~kg} \mathrm{ha}^{-1} \mathrm{~d}^{-1}$, respectively, happened from May to July, retrieving $\mathrm{WP}_{\mathrm{ET}}$ pixel values larger than $3.5 \mathrm{~kg} \mathrm{~m}^{-3}$. It was noticed some water stress conditions, with the fraction ET to reference evapotranspiration $\left(\mathrm{ET}_{0}\right)$ dropping below 0.60 from the start of August to the end of the year, affecting the $\mathrm{WP}_{\mathrm{ET}}$ values. Considering also WP in terms of fruits and coconut's water produced, it averaged 1.9 coconut fruits and $0.8 \mathrm{~L}$ of coconut water per cubic meter of water consumed, respectively. The results can support techniques for irrigation water storage at the palm root zones, while increasing dwarf coconut yield in Northeast Brazil.
\end{abstract}

\section{Introduction}

Coconut (Cocos nucifera L.) is commercially grown around the Word, between latitudes $20^{\circ} \mathrm{N}$ and $20^{\circ} \mathrm{S}$ (Carr, 2011). In Brazil, the cropped areas are mainly along the Northeast coast, where, in addition to the positive market aspects, the dwarf palms, under good crop and water management, can flower at nearly two years after seeding (Sousa et al., 2011). Depending on the environmental conditions, the coconut palms, at the production stage, can present water consumption from 100 to $240 \mathrm{~L} \mathrm{palm}^{-1} \mathrm{~d}^{-1}$ (Carr, 2011). However, research carried out by Cintra et al. (2009) revealed that irrigation water for dwarf coconut of $100 \mathrm{~L} \mathrm{palm}^{-1} \mathrm{~d}^{-1}$, was more efficient than the conventionally applied volume of $150 \mathrm{~L} \mathrm{palm}^{-1} \mathrm{~d}^{-1}$ in the Sergipe state, Northeast Brazil. Thus, coconut crop demands studies on how to optimize water productivity (WP).

WP may be defined as the ratio of the net benefits from crop, forestry, fishery, livestock and mixed agricultural systems to the amount of water required to produce those benefits. Considering vegetation, WP can be biomass production (BIO) per water consumed, including that originated from rainfall, irrigation, seepage and changes in root-zone storage (Molden et al., 2007). In general, irrigation managers are interested in yield per unit applied irrigation water, but the drawback is that not all irrigation water is used for generating crop production (Teixeira et al., 2009). In this paper, coconut WP is considered as the ratio of BIO by actual evapotranspiration (ET), but also in terms of fruits and coconut's water produced by ET.

Quantification and analyses of the coconut WP is important, rising in importance when considering the actual climate and land-use change conditions in some agricultural growing regions, with consequent water use competitions among different sectors (Jayakumar et al., 2017). These situations are currently happening in the coconut growing areas of Northeast Brazil, promoting a crescent demand for root-zone water conservation practices, which can improve WP, such as mulching with dry coconut leaves, and crushed coconut barks (Cintra et al., 2009;

\footnotetext{
* Corresponding author at: Av. Beira Mar, n. 3250, District Jardins, CEP 49025-040 Aracaju, SE, Brazil.

E-mail addresses: heriberto.teixeira@embrapa.br (A.H.d.C. Teixeira), fabio.miranda@embrapa.br (F.R. de Miranda), janice.leivas@embrapa.br (J.F. Leivas), edson.patto@embrapa.br (E.P. Pacheco), edlene.garcon@embrapa.br (E.A.M. Garçon).
} 
Resende et al., 2015).

Field measurements have been carried out in coconut crop to retrieve WP components, involving energy (Roupsard et al., 2006; Madurapperuma et al., 2009) and water balance (Azevedo et al., 2006; Miranda et al., 2007) techniques. However, these punctual studies fail to picture the spatial variation of the root-zone moisture and leaf area (Holtzman et al., 2018), bringing importance of up scaling tools for coconut water management decisions.

Remote sensing from satellite images, together with agrometeorological data, is a viable tool for determining the spatial variations of the coconut WP components, under different crop and water management. Several algorithms have been developed which can do this task, presenting advantages and shortcomings (Bhattarai et al, 2017; De La Foent-Sáiz et al., 2017; Wagle et al., 2017; Almeida et al., 2018; Ramírez-Cuesta et al, 2019). For operational purposes, applications of the Penman-Monteith (PM) equation has been suggested for retrieving these components at different spatial and temporal resolutions (Teixeira, 2010; Singh et al., 2014; Senay et al., 2017; Vanino et al., 2018).

Considering the operationally of the PM equation, the SAFER (Simple Algorithm for Evapotranspiration Retrieving) algorithm was developed to estimate ET, by coupling remote sensing parameters and agrometeorological data (Teixeira, 2010). After elaboration and validations in the Northeast Brazil, its applications in mixed Brazilian agroecosystems has been contributing to better knowledge of the WP components and other agrometeorological indices. These knowledges can subsidize water conservation practices without losing agricultural yield (Franco et al., 2016; Nuñez et al., 2017; Silva et al., 2018a, 2018b; Teixeira et al., 2018).

Despite remote sensing and field measurements for quantifying WP components had been carried out in several agro-ecosystems, only one by satellite images is found for the dwarf coconut crop in Brazil (Silva et al., 2012). On the other hand, most results from coconut field experiments did not consider WP based on ET. Instead, they did this based on irrigation (Roupsard et al., 2006; Miranda et al., 2007; Naresh Kumar et al., 2008; Cintra et al., 2009; Resende et al., 2015). Thus, there is still a lack of knowledge on the actual coconut water use and of yield responses to water consumed, needing approaches to address more information on WP based on ET (Carr, 2011). The challenge that remains, under the climate instability of the Northeast Brazil, is to quantify how little rather than how much water is needed to produce economically a viable dwarf coconut, considering different crop and water management.

The objective of this paper was to apply the SAFER algorithm (Teixeira, 2010), together with the Monteith's radiation use efficiency (RUE) model (Monteith, 1972), by using Landsat 8 images together with agrometeorological and yield data, to quantify and analyze the WP components for dwarf coconut crop. The results can subsidize crop and water management decisions, agro-climatic zonation, and irrigation scheduling in Northeast Brazil.

\section{Materials and methods}

\subsection{Study areas and data set}

Fig. 1 shows the study areas together with the agrometeorological station, inside the Boa Esperança farm, from Ducoco Alimentos S.A., in

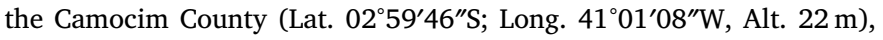
coastal zone of Ceará state, Northeast Brazil.

The Camocim County is located in the coastal zone of Ceará state, Northeast Brazil. This region presents two climatically distinct periods; one is dry and long, while the other one is humid, short and irregular, with the rains concentrated in the first half of the year (Kelting, 2010). The thermal regime is characterized by high air temperatures $\left(T_{a}\right)$, but presenting low thermal annual amplitudes, due proximity from Equator. The maximum $\mathrm{T}_{\mathrm{a}}$ values, averaging $30.7^{\circ} \mathrm{C}$, occur in
November, at the sun-zenith position and low cloud cover conditions, while the minimum ones are around $21.2^{\circ} \mathrm{C}$, in July, during the winter solstice (Moraes et al., 2006).

The crops on the farm are the cv. Jiqui dwarf coconut palms totaling 127 ha. The studied ones were planted in 2013, 2012 and 2011, inside the areas $\mathrm{A} 1, \mathrm{~A} 2$, and $\mathrm{A} 3$, respectively, as shown in Fig. 1, under a triangular spacing of $10 \mathrm{~m} \times 10 \mathrm{~m}\left(115\right.$ palms ha $\left.^{-1}\right)$, in a sandy, deep and well-drained soil. The average palm height was $5 \mathrm{~m}$ in 2016, being the crop daily micro-sprinkler irrigated by one emitter per palm, at a mean rate of $70 \mathrm{Lh}^{-1}$. Fertilizers were applied three times per year by using organic compost, and bunches were harvested each 21 days.

An agrometeorological station was installed close to the coconut areas (see Fig. 1), and the agrometeorological data used together with nine Landsat 8 satellite images, orbital/pointer 218/062, acquired at January 22, May 13, June 14, June 30, July 16, August 01, August 17, September 02 and November 05, involving different thermohydrological conditions during the year 2016. Data on global solar radiation $\left(\mathrm{R}_{\mathrm{G}}\right), \mathrm{T}_{\mathrm{a}}$ and reference evapotranspiration $\left(\mathrm{ET}_{0}\right)$ calculated by the Penman-Monteith method (Allen et al., 1998) were used together with remote sensing parameters, the surface albedo $\left(\alpha_{0}\right)$ and the Normalized Difference Vegetation Index (NDVI), for estimating the fraction of ET to $\mathrm{ET}_{0}\left(\mathrm{ET}_{\mathrm{f}}\right)$ through the SAFER algorithm, originally called PM2 by Teixeira (2010).

Under cloudy conditions, at some dates of the satellite revisit, interpolations taking successive average values of $\alpha_{0}$ and NDVI pixels, between these dates were performed for $\mathrm{ET}_{\mathrm{f}}$ acquirements, and the estimated $\mathrm{ET}_{\mathrm{f}}$ images used together with the daily agrometeorological data for these days, allowing continuous tracking of the coconut WP components along the year.

\subsection{Modelling coconut water productivity}

Fig. 2 shows the flowchart for acquirements of the coconut WP components, applying the SAFER and RUE models by using the visible and infrared bands from the Landsat 8 (L8) sensor together with agrometeorological data.

The L8 bands, from 1 to 7 (spatial resolution of $30 \mathrm{~m}$ ) were used for $\alpha_{0}$ and NDVI calculations, while surface temperature $\left(T_{0}\right)$ was estimated by applying the residual method having acquired all the radiation balance terms. Teixeira et al. (2016) have validated the SAFER algorithm by using Landsat images without the thermal band in the Northeast Brazil. According to Mokhtari et al. (2019), several other recent studies have demonstrated the suitability of retrieving the WP components without the satellite thermal bands (Castelo et al., 2018; Rozenstein et al., 2018; Vanino et al., 2018). The option for estimating $\mathrm{T}_{0}$ by the residual method (Teixeira et al., 2016) in the current study, was due to problems with some pixels in the L8 thermal bands 10 and 11 (spatial resolution of $100 \mathrm{~m}$ ), including clouds, while bringing all the results to a better $30 \mathrm{~m}$ spatial resolution. Besides, the $\mathrm{L} 8$ visible and infrared bands were resampled to a $5 \mathrm{~m}$ pixel sizes, by using a RapidEye image acquired in the year 2014 (image in the left side of Fig. 1).

All the regression coefficients in Fig. 2 were previously determined in Northeast Brazil, by simultaneous Landsat and field measurements, involving strongly contrasting agro-ecosystems and thermohydrological conditions throughout several years (Teixeira et al., 2008; Teixeira, 2010). Field data used for model elaboration and validations involved sparse irrigated crops and natural vegetation (Caatinga) from 2001 to 2007 (Teixeira et al., 2008). Table grapes were micro sprinkler irrigated conducted by an overhead trellis system; wine grapes were drip irrigated carried out by a vertical trellis system; mango orchard was micro sprinkler irrigated; and measurements in Caatinga involved mixed species under different rainfall conditions. In addition, $\mathrm{ET}_{\mathrm{f}}$ values under optimum soil-moisture conditions in the current coconut study were checked with the crop coefficient $\left(\mathrm{K}_{\mathrm{c}}\right)$ approach (Allen et al., 1998) from literature. Thus, with all these strongly contrasting conditions and assumptions, one can expect sufficient accuracy for coconut WP 

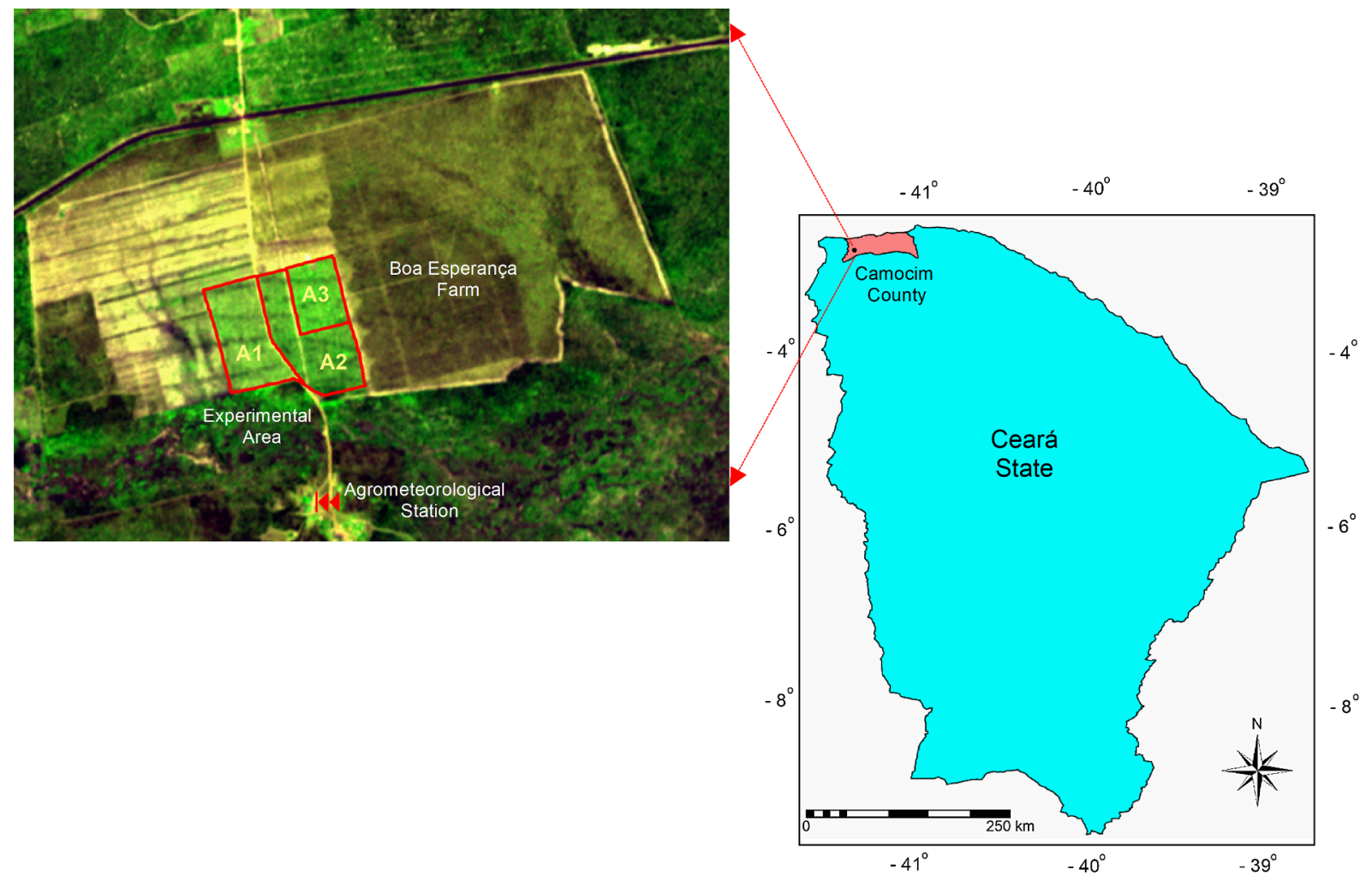

Fig. 1. Location of the study areas together with the agrometeorological station, in the Camocim County, coastal zone of Ceará state, Northeast Brazil.

analyses under the Brazilian Northeast conditions.

Following Fig. 2, the spectral radiances $\left(\mathrm{L}_{\mathrm{b}}\right)$ from bands (b) 1-7, were computed from its Digital Numbers $\left(\mathrm{DN}_{\mathrm{b}}\right)$ :

$$
L_{b}=\text { Gain } \times D N_{b}+\text { Offset }
$$

where Gain and Offset refer to the values given in the metadata file (Vanhellemont and Ruddick, 2014).

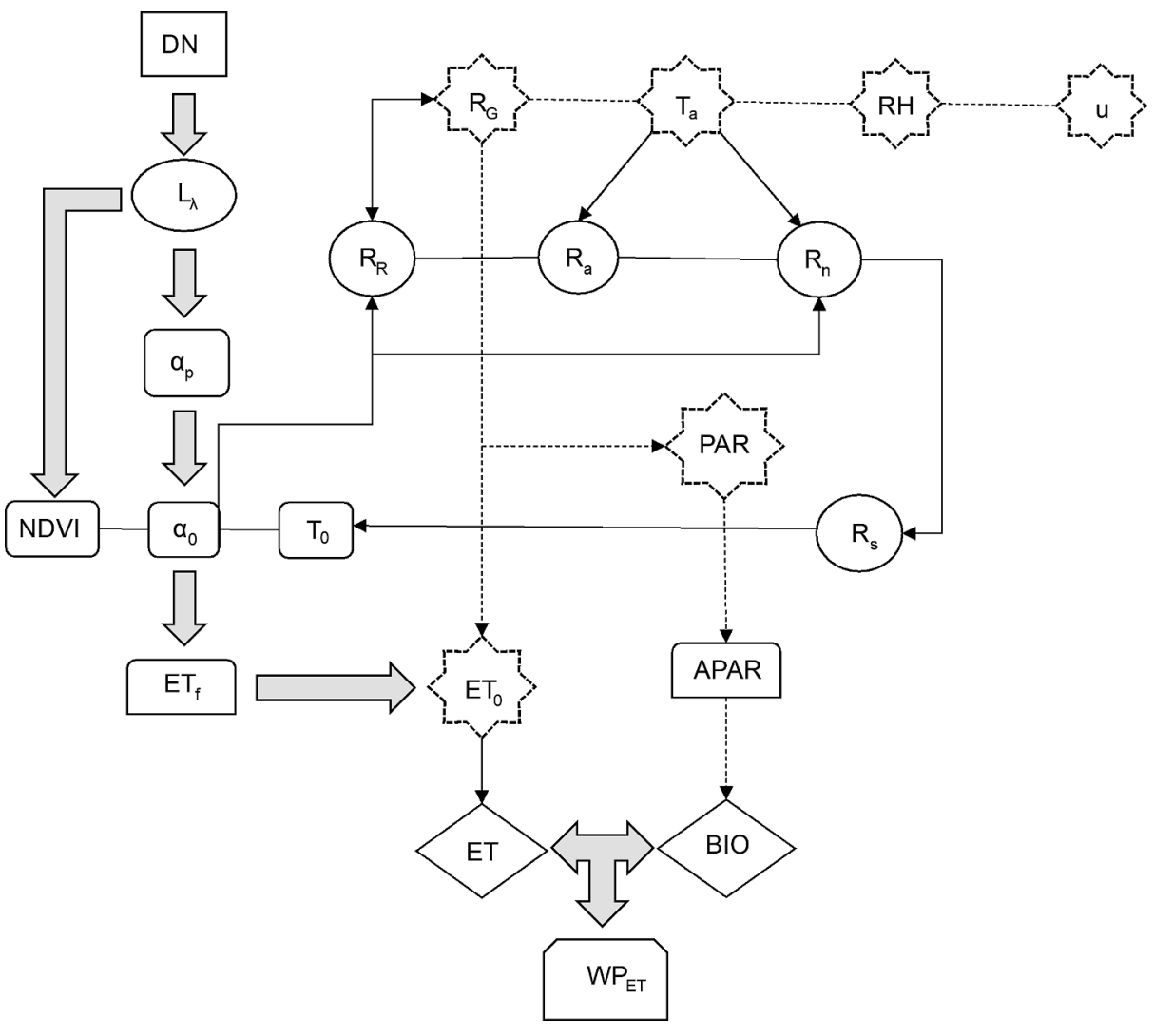

Fig. 2. Flowchart for acquiring the water productivity (WP) components for coconut crop, applying the SAFER and RUE models by using the visible and infrared bands from the Landsat 8 sensor together with agrometeorological data. Note: $D N$ - Digital number; $R_{G}$ - Incident global solar radiation; $\mathrm{T}_{\mathrm{a}}$ - Mean air temperature; $\mathrm{RH}$ Relative humidity; $\mathrm{u}$ - wind speed; $\mathrm{L}_{\lambda}$ - Spectral radiation for each band; $R_{R}$ - Reflected global solar radiation; $R_{a}$ - Emitted atmospheric radiation; $R_{n}$ Net radiation; $\alpha_{\mathrm{p}}$ - Planetary albedo; PAR Photosynthetically active radiation; NDVI Normalized Difference Vegetation Index; $\alpha_{0}$ Surface albedo; $\mathrm{T}_{0}$ - Surface temperature; $\mathrm{R}_{\mathrm{s}}$ Emitted surface radiation; $\mathrm{ET}_{\mathrm{f}}$ - Evapotranspiration fraction; $\mathrm{ET}_{0}$ - Reference evapotranspiration; APAR

- Absorbed photosynthetically active radiation; ET - Actual evapotranspiration; BIO - Biomass production; $\mathrm{WP}_{\mathrm{ET}}-$ Water productivity based on ET. 
The planetary albedo for each Landsat satellite band $\left(\alpha \mathrm{p}_{\mathrm{b}}\right)$ was calculated as:

$\alpha p_{b}=\frac{L_{b} \pi d^{2}}{R a_{b} \cos \varphi}$

where $L_{b}$ is in $\mathrm{W} \mathrm{m}^{-2} \mathrm{sr}^{-1} \mu \mathrm{m}^{-1}, \mathrm{~d}$ is the relative earth-sun distance; $\mathrm{Ra}_{\mathrm{b}}$ is the mean solar irradiance at the top of the atmosphere (or atmospheric irradiance) for each band $\left(\mathrm{W} \mathrm{m}^{-2} \mu \mathrm{m}^{-1}\right)$, and $\varphi$ the solar zenith angle.

$\mathrm{Ra}_{\mathrm{b}}$ was calculated according to the Planck's low, integrating the radiation over the wavelength intervals and considering its fraction over the solar spectrum, assuming the sun as a blackbody. Then, the broadband planetary albedo $\left(\alpha_{p}\right)$ was calculated as the total sum of the different narrow-band $\alpha_{p b}$ values, according to the weights for each band $\left(\mathrm{w}_{\mathrm{b}}\right)$.

$\alpha_{p}=\sum w_{b} \alpha_{p b}$

where the $\mathrm{w}_{\mathrm{b}}$ values were computed as the ratio of the incoming shortwave radiation from the sun at the top of the atmosphere in a particular band and the sum for all the bands.

For $\alpha_{0}$ estimations, atmospheric corrections were done for $\alpha_{\mathrm{p}}$, considering both satellite overpass and the 24-hour values, throughout regression equations from previous coupled field and Landsat measurements (Teixeira et al., 2008; Teixeira, 2010).

The atmospheric radiation $\left(\mathrm{R}_{\mathrm{a}}\right)$ was calculated throughout the Stefan-Boltzmann law:

$R_{a}=\sigma \varepsilon_{A} T_{a}^{4}$

where $\sigma$ is the Stefan-Boltzmann constant $\left(5.67 \times 10^{-8} \mathrm{~W} \cdot \mathrm{m}^{-2} \cdot \mathrm{K}^{-4}\right)$, $\mathrm{T}_{\mathrm{a}}$ was measured at the agrometeorological station, and the atmospheric emissivity $\left(\varepsilon_{\mathrm{A}}\right)$ were calculated as (Teixeira et al., 2008):

$\varepsilon_{A}=a_{A}\left(\ln \tau_{s w}\right)^{b_{A}}$

with $\mathrm{a}_{\mathrm{A}}$ and $\mathrm{b}_{\mathrm{A}}$ being the regression coefficients.

With measured $R_{G}$ at the agrometeorological station and $\alpha_{0}$ acquired from remote sensing measurements, the daily values of the reflected solar radiation $\left(\mathrm{R}_{\mathrm{R}}\right)$ were calculated:

$R_{R}=\alpha_{0} R_{G}$

To retrieve $T_{0}$ by the residual method, the $R_{n}$ daily values were estimated throughout the Slob equation:

$R_{n}=\left(1-\alpha_{0}\right) R_{G}-\left(a_{L} \tau\right)$

where $\tau$ is the atmospheric transmissivity, calculated $\left(\mathrm{R}_{\mathrm{G}} / \mathrm{R}_{\mathrm{a}}\right)$ and $\mathrm{a}_{\mathrm{L}}$ is the regression coefficient, which in turn was correlated with $T_{a}$ (Teixeira et al., 2008).

Having $R_{G}, R_{R}, R_{a}$, and $R_{n}$, the longwave emitted radiation by the cropped surface $\left(R_{s}\right)$ was obtained as residue in the radiation balance:

$R_{s}=R_{G}-\mathrm{R}_{\mathrm{R}}+\mathrm{R}_{\mathrm{a}}-\mathrm{R}_{\mathrm{n}}$

The daily residual $\mathrm{T}_{0}$ values were then estimated as:

$T_{0}=\sqrt[4]{\frac{R_{S}}{\sigma \varepsilon_{S}}}$

being $\varepsilon_{\mathrm{S}}$ the surface emissivity estimated according to Teixeira et al. (2018):

$\varepsilon_{s}=a_{s} \ln N D V I+b_{s}$

where $a_{s}$ and $b_{s}$ are regression coefficients.

The daily values of the ET to $\mathrm{ET}_{0}$ fraction $\left(\mathrm{ET}_{\mathrm{f}}\right)$ were modeled:

$E T_{f}=\exp \left[a_{s f}+b_{s f}\left(\frac{T_{0}}{\alpha_{0} N D V I}\right)\right]$

where $a_{s f}$ and $b_{s f}$ are regression coefficients.

The $\mathrm{ET}_{\mathrm{f}}$ images were multiplied by $\mathrm{ET}_{0}$ to retrieve the daily $\mathrm{ET}$ values. (Franco et al., 2016; Nuñez et al., 2017; Silva et al., 2018a,b; Teixeira et al., 2018):

$E T=E T_{f} E T_{0}$

The photosynthetically active radiation (PAR) was estimated by:

$P A R=a_{p} R_{G}$

where $a_{p}$ is a regression coefficient found to be 0.44 for the Northeast Brazil (Teixeira et al., 2008).

The absorbed PAR (APAR) was calculated as:

$A P A R=f_{p} P A R$

being $\mathrm{f}_{\mathrm{p}}$ estimated from NDVI (Bastiaanssen and Ali, 2003):

$f_{P}=b_{p} N D V I+c_{p}$

where $b_{p}$ and $c_{p}$ are regression coefficients.

For BIO calculations, the Monteith's RUE model (Monteith, 1972) was used, introducing the moisture effect through $\mathrm{ET}_{\mathrm{f}}$ (Teixeira et al., 2018):

$B I O=\sum\left(\varepsilon_{\max } E T_{f} A P A R 0.864\right)$

where $\varepsilon_{\max }$ is the maximum radiation efficiency use and 0.864 is the unit conversion factor. For coconut, $\varepsilon_{\max }$ of $2.4 \mathrm{~g} \mathrm{MJ}^{-1}$ was used (Naresh Kumar et al., 2008).

Besides WP being considered as the ratio of BIO to ET (WP $\mathrm{WT}_{\mathrm{ET}}$, with yield data available, it was also analyzed in terms of coconut fruits and coconut water volume by ET ( $\mathrm{WP}_{\mathrm{CcFt}}$ and $\mathrm{WP}_{\mathrm{CcWt}}$, respectively).

\section{Results and discussion}

\subsection{Weather conditions}

As coconut ET and BIO rates will depend on the weather conditions, firstly, the rainfall amounts and parameters related to the atmospheric demands and photosynthetic activities were analyzed, at daily timescale, during the year 2016. Fig. 3 shows the tendencies for pluvial precipitation (P) and $\mathrm{ET}_{0}$ (a) together with those for $\mathrm{R}_{\mathrm{G}}$ and $\mathrm{T}_{\mathrm{a}}(\mathrm{b})$, in terms of Day of the Year (DOY).

According to Naresh Kumar (2008) a well distributed rainfall of $1300-2300 \mathrm{~mm} \mathrm{yr}^{-1}$, with a mean $\mathrm{T}_{\mathrm{a}}$ of $27.0 \pm 5.0^{\circ} \mathrm{C}$ and $\mathrm{R}_{\mathrm{G}}$ around 21-30 MJ m ${ }^{-2} \mathrm{~d}^{-1}$, provides optimum conditions for coconut growth and yield. When rainfall is not enough to meet the crop water requirements, the palms need irrigation (Jayakumar et al., 2017). According to Fig. 3a, rainfalls were concentrated in the first half of the year, with $\mathrm{P}$ daily values above $30 \mathrm{~mm}$ on several occasions, not needing irrigation. Although the annual total of $1309 \mathrm{~mm}$ staying at the lower end of the ideal range reported by Naresh Kumar et al. (2008), from July (DOY 191) to the end of the year, rains were absent, similar conditions of the local climatological pattern (Kelting, 2010). Regarding the atmospheric demand, as the study farm is close to equator, the $\mathrm{ET}_{0}$ amplitude was short, with the highest values starting in September (DOY 245), overcoming $5.0 \mathrm{~mm} \mathrm{~d}^{-1}$, intensifying the water deficit in the climatic water balance. Thus, for good coconut production levels, because of the dryness of the climate, irrigation is essential during the second half of the year.

According to $\mathrm{R}_{\mathrm{G}}$ tendencies (Fig. $3 \mathrm{~b}$ ), the maximum levels were from DOY 219 (August 06) to DOY 346 (December 11), when the daily values were higher than $20 \mathrm{MJ} \mathrm{m}^{-2} \mathrm{~d}^{-1}$. The minimum ones occurred during the rainy period, between DOY 074 (March 14) and DOY 117 (April 22), when the cloud cover was significant, with $R_{G}$ dropping below $15 \mathrm{MJ} \mathrm{m}^{-2} \mathrm{~d}^{-1}$, in some days. However, during most of the periods along the year, $R_{G}$ was inside the optimum conditions for coconut BIO reported by Jayakumar et al. (2017), in a range from 7.6 to 23.4 $\mathrm{MJ} \mathrm{m}^{-2} \mathrm{~d}^{-1}$. Daily $\mathrm{T}_{\mathrm{a}}$ values (Fig. $3 \mathrm{~b}$ ), in general followed those for $\mathrm{R}_{\mathrm{G}}$. However, inside the rainy season, some high $\mathrm{T}_{\mathrm{a}}$ values happened 

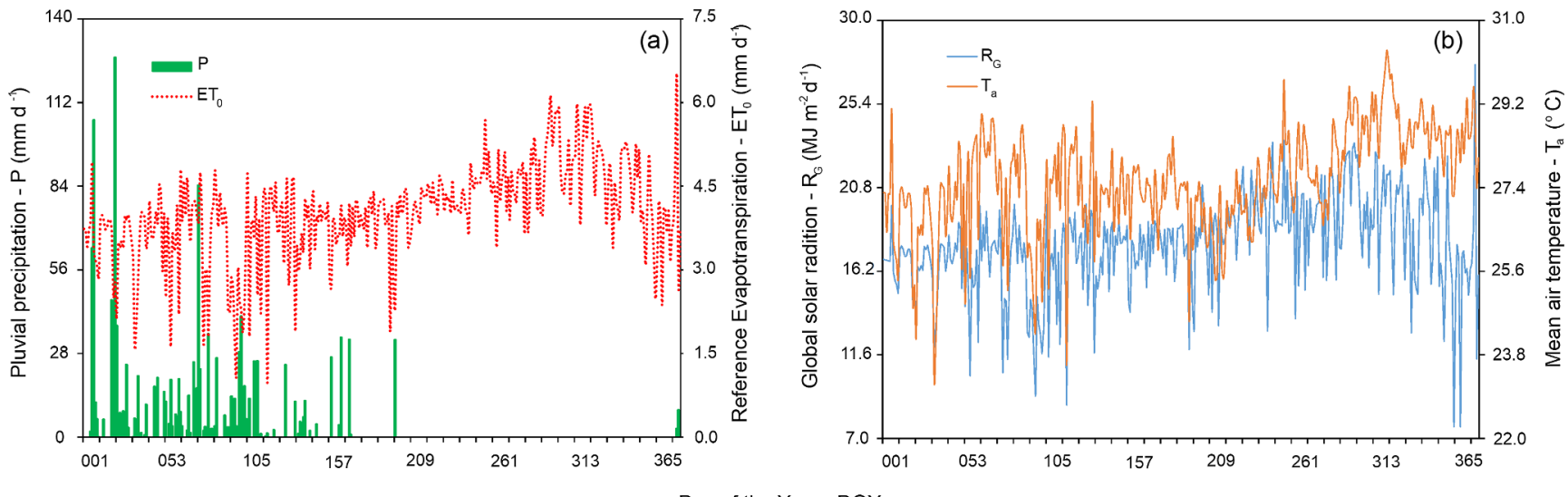

Day of the Year - DOY

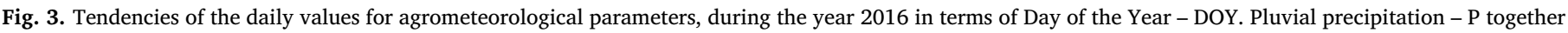
with reference evapotranspiration $-\mathrm{ET}_{0}(\mathrm{a})$; and global solar radiation $-\mathrm{R}_{\mathrm{G}}$ together with mean air temperature $-\mathrm{T}_{\mathrm{a}}(\mathrm{b})$.

under low $\mathrm{R}_{\mathrm{G}}$ levels. The hottest period was from DOY 276 (October 02) to the end of the year, when $\mathrm{T}_{\mathrm{a}}$ was larger than $28.0^{\circ} \mathrm{C}$, while the coldest one was in July (DOY 183-213), when $\mathrm{T}_{\mathrm{a}}$ dropped below $26.0{ }^{\circ} \mathrm{C}$. The $\mathrm{T}_{\mathrm{a}}$ levels were also within the optimum thermal conditions for coconut pointed out by Jayakumar et al. (2017).

\subsection{Coconut water productivity}

Fig. 4 shows the spatial distributions and averages of the WP quarterly (Q) daily values for the irrigated dwarf coconut, involving different palm ages and thermohydrological conditions during the year 2016, in the Camocim County, coastal zone of the Ceará state, Northeast Brazil.

Clearly one can see spatial differences on ET, BIO and $\mathrm{WP}_{\mathrm{ET}}$ pixel values in the A1 (three-year-old palms), A2 (four-year-old palms), and A3 (five-year-old palms) dwarf coconut areas, accordingly to the period of the year. The largest values for all WP components occurred in the second quarter (Q2), at the end of the rainy period, conditions of high root-zone moisture, but for both, coconut palms and inter-row weeds. The lowest ones were during the third quarter (Q3), the climatically driest period of the year, when coconut palms was covering only $50 \%$ of the soil and receiving localized irrigation water, while inter-row weeds dried out.

The highest ET and BIO spatial variations were in Q1, inside the rainy season, when the standard deviations (SD) were respectively $19 \%$ and $25 \%$ of the average pixel values. On the other hand, the lowest SD values happened in Q2, just after the rains, when they were respectively 16 and $22 \%$ of the average pixel values. In case of $\mathrm{WP}_{\mathrm{ET}}$, these corresponding limits were in Q3 (11\%) and Q1 (8\%).

Fig. 5 presents the tendencies of the ET, BIO and $\mathrm{WP}_{\mathrm{ET}}$ daily average pixel values, in terms of day of the year (DOY), for the dwarf coconut areas, with palms three (A1), four (A2), and five (A3) years old, during the year 2016, in the Camocim County, coastal zone of the Ceará state, Northeast Brazil.

The largest ET values occurred from May to July (DOY 150-214), reaching to mean rates of $4.5 \mathrm{~mm} \mathrm{~d}^{-1}$ for the three-year-old palms (A1 area). During this peak period, the maximum rates in the A2 and A3 areas, four and five-year-old palms, were 4.3 and $4.1 \mathrm{~mm} \mathrm{~d}^{-1}$, respectively. The lowest ET values, considering all coconut areas, were around $1.0 \mathrm{~mm} \mathrm{~d}^{-1}$, happening in April (DOY 102), at the end of the rainy period, while the annual averages ranged from 2.6 to $2.9 \mathrm{~mm} \mathrm{~d}^{-1}$ among the different palm ages.

From remote sensing measurements, Silva et al. (2012) found ET values ranging from 4.4 to $5.6 \mathrm{~mm} \mathrm{~d}^{-1}$, when applying SEBAL algorithm to Landsat images in a five-year-old irrigated dwarf coconut, during the hottest conditions of the semi-arid region in the Paraíba state, Northeast Brazil. By using the METRIC model, also to Landsat images, Folhes et al. (2009), reported ET rates between 3.0 and $6.0 \mathrm{~mm}$ $\mathrm{d}^{-1}$ in irrigated fruit crops, under the semi-arid conditions of the Ceará state, Northeast Brazil.

Regarding field measurements, in Sergipe state, coastal zone of the Northeast Brazil, through the soil water balance approach, Azevedo et al. (2006) found mean ET values from 2.5 to $3.2 \mathrm{~mm} \mathrm{~d}^{-1}$ for six-yearold dwarf coconut palms, varying according to the irrigation water applied levels. Also in Sergipe and for dwarf coconut, Sousa et al. (2011), from lysimetric measurements, reported average values of $3.9 \mathrm{~mm} \mathrm{~d}^{-1}$ in a range from 2.0 to $5.6 \mathrm{~mm} \mathrm{~d}^{-1}$. In the coastal zone of the Ceará state, Northeast Brazil, Miranda et al. (2007), using the soil water balance method, found maximum ET of $5.0 \mathrm{~mm} \mathrm{~d}^{-1}$ for a threeyear-old dwarf coconut, averaging $3.9 \mathrm{~mm} \mathrm{~d}^{-1}$, when the crop aged four years. Carr (2011) presented a summary of average ET for mature dwarf coconut ranging from 1.7 to $5.0 \mathrm{~mm} \mathrm{~d}^{-1}$. According to this last author, a typical coconut ET rate should be probably $3.0-3.5 \mathrm{~mm} \mathrm{~d}^{-1}$. One of the reasons for the ET differences between field and remote sensing measurements is that for the satellite image cases, the results represent average pixel values.

As there is a relation between ET and BIO, maximum values for both WP components occurred at the same periods, with BIO reaching to daily rates of $170 \mathrm{~kg} \mathrm{ha}^{-1} \mathrm{~d}^{-1}$ in $\mathrm{A} 1$ area (three-year-old palms). The maximum BIO values in A2 (four-year-old palms) and A3 (five-year-old palms) areas were 137 and $132 \mathrm{~kg} \mathrm{ha}^{-1} \mathrm{~d}^{-1}$, respectively. However, the lowest BIO, around $36 \mathrm{~kg} \mathrm{ha}^{-1} \mathrm{~d}^{-1}$, considering all coconut areas, occurred in February (DOY 054), inside the rainy period, as a consequence of declining $R_{G}$ levels that limited the photosynthetic activity. The mean annual BIO ranged from 73 to $84 \mathrm{~kg} \mathrm{ha}^{-1} \mathrm{~d}^{-1}$ among all palm ages.

Under different agro-climatic zones in India, simulated average BIO values ranged from 93 to $100 \mathrm{~kg} \mathrm{ha}^{-1} \mathrm{~d}^{-1}$ for irrigated coconuts (Naresh Kumar et al., 2008), little higher than those for the current study. In the agricultural growing region of the North of Minas Gerais state, semi-arid conditions of Southeast Brazil, Teixeira et al. (2018), reported BIO values between $78 \pm 62$ and $132 \pm 64 \mathrm{~kg} \mathrm{ha}^{-1} \mathrm{~d}^{-1}$, for different irrigated crops. The similarity between these last values and those from the current study brings confidence of the applied models for WP coconut assessments in the coastal zone of the Northeast Brazil.

In relation to $\mathrm{WP}_{\mathrm{ET}}$ results, the maximums values coincided with those for ET and BIO, reaching to $3.7 \mathrm{~kg} \mathrm{~m}^{-3}$ in A1 area (three-year-old palms). During this period, those for A2 (four-year-old palms) and A3 (five-year-old palms) were 3.4 and $3.3 \mathrm{~kg} \mathrm{~m}^{-3}$, respectively. The lowest $\mathrm{WP}_{\mathrm{ET}}$ values, around $2.3 \mathrm{~kg} \mathrm{~m}^{-3}$, occurred from September to November (DOY 262-310), for all palm ages. Nuñez et al. (2017), applying the SAFER algorithm and the RUE model to Landsat 8 images in 


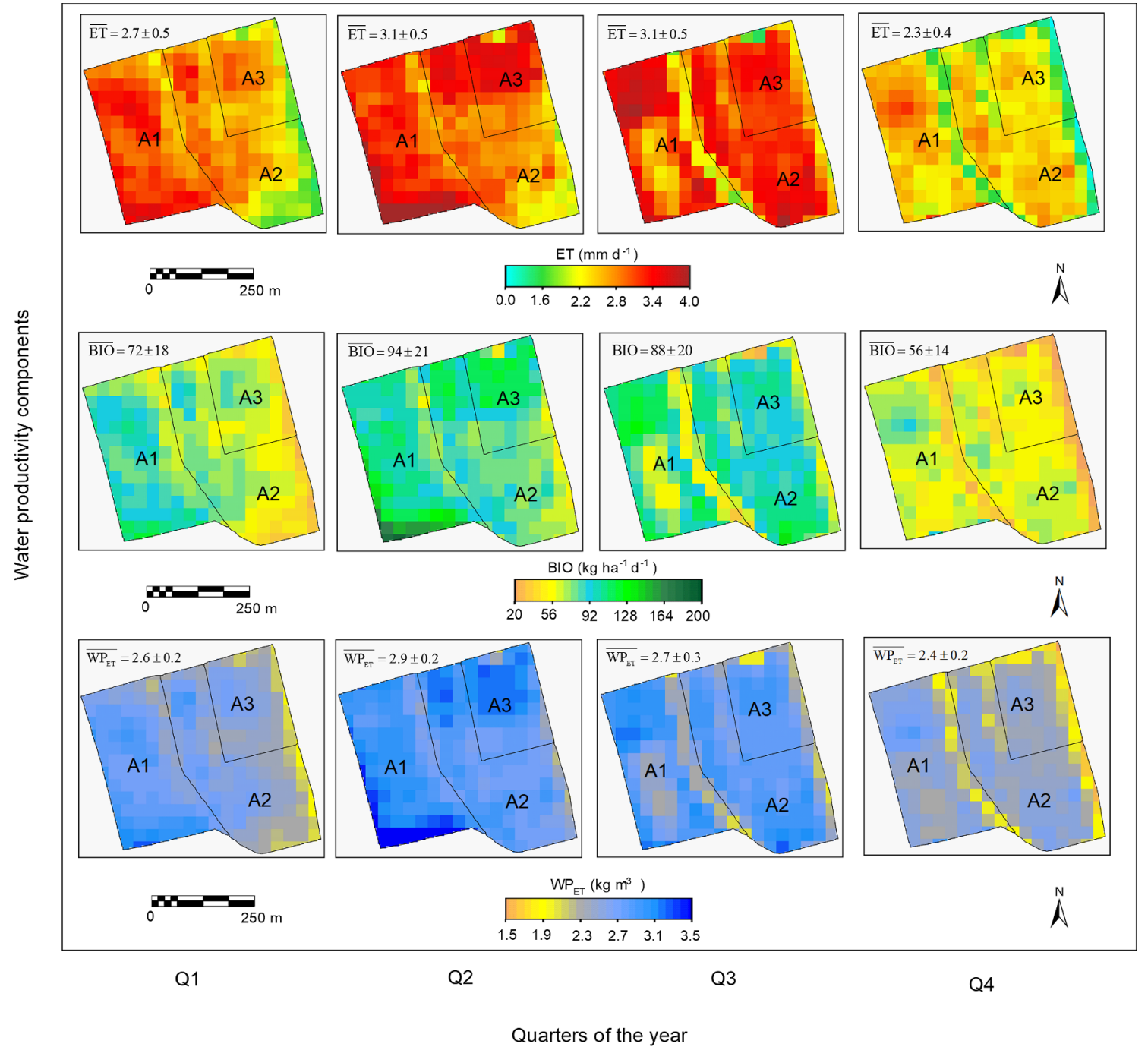

Fig. 4. Spatial distributions and averages of the WP quarterly (Q) daily values for the irrigated dwarf coconut during 2016, with palms aging three (A1), four (A2), and five (A3) years. ET - Actual evapotranspiration; BIO - Biomass production; and $\mathrm{WP}_{\mathrm{ET}}$ - Water productivity based on ET.

the northwestern side of São Paulo state, Southeast Brazil, found average $\mathrm{WP}_{\mathrm{ET}}$ of $3.4 \mathrm{~kg} \mathrm{~m}^{-3}$ for perennial crops, similar to our dwarf coconut results.

Having available 21-day periods of yield and ET data in the A2 area (four-year-old palms), from DOY 095-357 (April to December), it was possible to analyze WP in terms of fruits and coconut water $\left(\mathrm{WP}_{\mathrm{CcFt}}\right.$ and $\mathrm{WP}_{\mathrm{CcWt}}$, respectively). Fig. 6 shows the coconut fruits - CcFt and coconut water - CcWt produced at this time-scale (a), and the relationship between the accumulated values for coconut water $-\mathrm{CcWt}_{\mathrm{ac}}$ and biomass production $-\mathrm{BIO}_{\mathrm{ac}}(\mathrm{b})$.

According to Fig. $6 \mathrm{a}$, the highest CcFt and CcWt values, in the 8.1 ha of the A2 area, were from DOY 211 (July 29) to 273 (September 29), when reached to peaks above 500 fruits $\mathrm{d}^{-1}$ and $225 \mathrm{~L} \mathrm{~d}^{-1}$, respectively. The lowest ones happened between DOY 147 (May 26) and 168 (June 16), when dropped respectively below 230 fruits $\mathrm{d}^{-1}$ and $120 \mathrm{~L}$ $\mathrm{d}^{-1}$. From Fig. $6 \mathrm{~b}$ it is noticed the high correlation between $\mathrm{CcWt}_{\mathrm{ac}}$ and $\mathrm{BIO}_{\mathrm{ac}}$, with the variations on $\mathrm{BIO}_{\mathrm{ac}}$ explaining $95 \%$ of those for $\mathrm{CcWt}_{\mathrm{ac}}$. From May to December of 2016, coconut fruit productivity ranged from 29 to 62 fruits ha ${ }^{-1} \mathrm{~d}^{-1}$, while for the coconut water volume it was within 310-585 L ha ${ }^{-1} \mathrm{~d}^{-1}$. Naresh Kumar et al. (2008) reported coconut productivity levels from 19 to 75 fruits $\mathrm{ha}^{-1} \mathrm{~d}^{-1}$, but involving various agro-climatic zones and different irrigated giant and dwarf varieties in India. According to these last authors, modelling $\mathrm{BIO}_{\mathrm{ac}}$ allows estimations of carbon sequestration potentials and carbon stocks in dwarf coconut plantations.

$\mathrm{WP}_{\mathrm{CcFt}}$ and $\mathrm{WP}_{\mathrm{CcWt}}$ mean values ranged from 0.9 to 2.5 fruits and 0.5-1.2 L of coconut water per cubic meter of water consumption, in DOY 147 (May 26) - 189 (July 07) and from 273 (September 29) to 294 (October 20). The respective annual averages were 1.9 fruits $\mathrm{m}^{-3}$ and $0.8 \mathrm{~L} \mathrm{~m}^{-3}$. From a soil-water balance experiment, Azevedo et al. (2006), reported higher $\mathrm{WP}_{\mathrm{CcWt}}$ values, ranging from 3.0 to $2.8 \mathrm{~L} \mathrm{~m}^{-3}$, in Sergipe state, Northeast Brazil, with increasing irrigation water level from 50 to $150 \mathrm{~L} \mathrm{palm}^{-1}$.

Taking into account the local price of US\$ 0.50 for liter of coconut

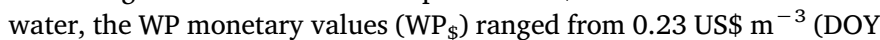
168-169, June 16 to July 07) to 0.58 US $\$ \mathrm{~m}^{-3}$ (DOY 273-294, September 29 to October 20. Teixeira et al. (2009) reported $\mathrm{WP}_{\$}$ values from 0.36 to 1.55 US $\$ \mathrm{~m}^{-3} ; 2.24-5.10$ US $\$ \mathrm{~m}^{-3}$; and 3.74-8.80 US\$ $\mathrm{m}^{-3}$, for respectively irrigated wine grape, mango, and seedless table grape, in the semi-arid region of Northeast Brazil. Comparing our WP results with those from literature it is evidenced the need for improvements on irrigation management of dwarf coconut crop, as for instance, by using root-zone moisture conservation techniques.

\subsection{Coconut root-zone moisture}

The analyses of the root-zone moisture tendencies, along the year 2016, were carried out by the $\mathrm{ET}_{\mathrm{f}}$ index (see Eq. (11)), considering the 

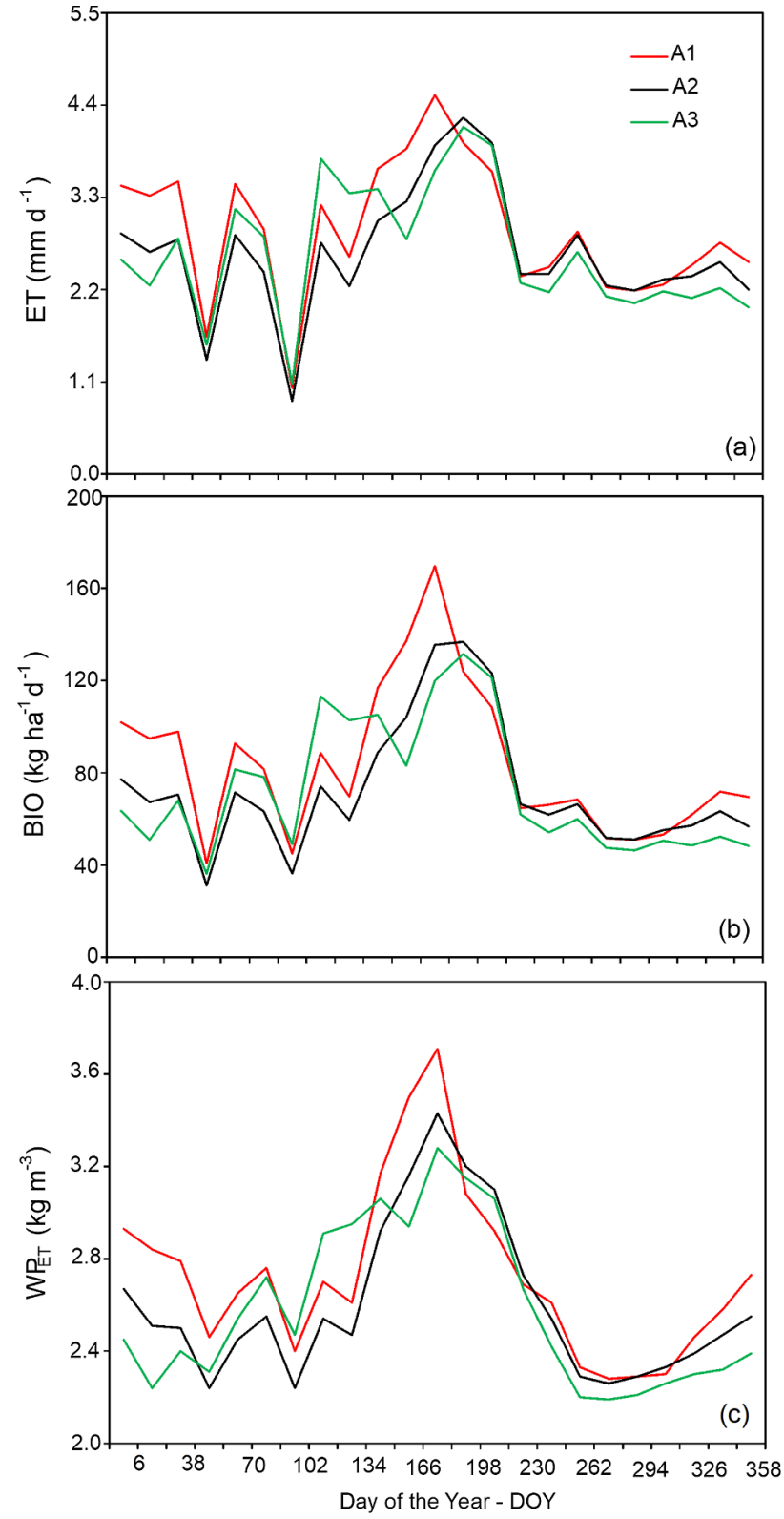

Fig. 5. Tendencies of the daily mean pixel values for actual evapotranspiration (ET), biomass production (BIO), and water productivity based on ET (WP $\mathrm{ET}_{\mathrm{ET}}$ ), in terms of day of the year (DOY), inside the areas with three (A1), four (A2), and five (A3) years old dwarf coconut palms.

different palm ages, through the average pixel values in A1, A2, and A3 dwarf coconut areas. However, the irrigation water amounts $(\mathrm{mm})$ were monitored by hydrometer only in A2 (four-year-old palms) area (Fig. 7).

Despite the similar WP tendencies among the all dwarf coconut areas, the $\mathrm{ET}_{\mathrm{f}}$ average values ranged between 0.46 in October (DOY 294) in A3 and 1.08 in June (DOY 166-182) in A1, areas with respectively five and three-year-old palms. The highest $\mathrm{ET}_{\mathrm{f}}$ values can be considered as the crop coefficient - $K_{c}$ (Mokhtari et al., 2019). According to Carr (2011), The $\mathrm{K}_{\mathrm{c}}$ values for mature coconut crop range from 0.50 to 1.02 , with some evidence of seasonal variability, however, for immature palms they should be probably lower.

Excepting from September 02 (DOY 246) to November 05 (DOY 310), when $\mathrm{ET}_{\mathrm{f}}$ values dropped below 0.50 , the palm root-zones were well water supplied, with the annual $\mathrm{ET}_{\mathrm{f}}$ averages from 0.69 (A2 and $\mathrm{A} 3$ areas) to 0.76 ( $\mathrm{A} 1$ area), respectively. From the similarity on $\mathrm{ET}_{\mathrm{f}}$ values outside the rainy period, disregarding palm ages, it could be assumed no strong differences on irrigation water management among the dwarf coconut areas.

The lower $\mathrm{ET}_{\mathrm{f}}$ values from September to November (DOY 230-310) mean a gap between ET and the atmospheric demand, what should be unfavorable for coconut yield (Madurapperuma et al., 2009). At the end of the rainy period, previously accumulated irrigation of $134 \mathrm{~mm}$, between May 16 and June 16, was not enough to compensate the water consumed and/or percolated, pointing out water stress conditions in the palm root zones. Miranda et al. (2004) reported that more than $80 \%$ of the absorptive dwarf coconut roots are located till $0.60 \mathrm{~m}$ soil depth in the study region.

It must be considered that during the first half of the year, all cropped areas were covered by the dwarf coconut palms and inter-row vegetation, due to rainfall (see Fig. 3). Then, the optimum soil moisture beneficed both types of vegetation. After this period, however, the invasive plants dried out, due to the localized irrigation. Because of the large spaces between palms, the soil cover and moist fractions by the irrigation system, estimated from field measurements, were only 0.45 and 0.32 , respectively, what reduced ET while the atmospheric demand increased, hence dropping $\mathrm{ET}_{\mathrm{f}}$.

According to Roupsard et al. (2006), the ET partition into transpiration (T) and evaporation (E) between coconut palms and inter-row vegetation is considerably important to understand the water requirements and competition mechanisms. These authors, separating $\mathrm{T}$ and $\mathrm{E}$ measurements by the sap flow method in coconut crop, found $\mathrm{T}$ representing $68 \%$ of $\mathrm{ET}$, for a $75 \%$ of soil covered by the palms, much larger than that for the current study.

Silva et al. (2012), from remote sensing measurements, reported an $\mathrm{ET}_{\mathrm{f}}$ average value of 0.73 , for a dwarf coconut in a triangular space of $7.5 \times 7.5 \mathrm{~m}$ in Paraíba state. Under the same palm space, Miranda et al. (2007), applying the soil water balance in Ceará state, found $\mathrm{ET}_{\mathrm{f}}$ values ranging from 0.63 to 1.02 . Both studies were in coastal areas of the Northeast Brazil, which results were very similar to ours outside the driest period. Roupsard et al. (2006) by using the eddy covariance method for estimating ET, obtained average $\mathrm{ET}_{\mathrm{f}}$ values of 0.79 and 0.59 for the cool and for the warm seasons, respectively, in the Republic of Vanuatu, South Pacific Ocean. Carr (2011) presented a summary of average $\mathrm{ET}_{\mathrm{f}}$ ranging from 0.37 to 1.02 for mature dwarf coconut.

According to Li et al. (2016), $\mathrm{WP}_{\mathrm{ET}}$ is more affected by agronomy practices than by climatic factors, and its improvements should be based on advanced technologies involving crop and water management. The current research brought the attention for controlling inter-row invasive species during the rainy period, as for instance, by using mulching, concentrating the water consumption only for the dwarf coconut palms, while reducing the invasive species. Jayakumar et al. (2017), through a field experiment in Coimbatore, India, reported the benefits of polythene mulching on hybrid coconut, which increased plant height, canopy development, spathe length, number of inflorescence, number of bunches/palm/year and number of fruits/ bunch, raising $\mathrm{WP}_{\mathrm{ET}}$ when compared with the control treatment without mulch. In addition, mulching can help root-zone moisture conservation during the following climatically drier periods after the rainy season, minimizing the crop water stress (Carr, 2011; Resende et al., 2015).

\section{Conclusions}

The joint use of Landsat 8 (L8) and an agrometeorological station allowed quantification and analyses of the water productivity components for irrigated dwarf coconut, under different ages, in the coastal zone of the Ceará state, Northeast Brazil. It was demonstrated that daily values of actual evapotranspiration (ET), biomass production (BIO) and water productivity based on $\mathrm{ET}\left(\mathrm{WP}_{\mathrm{ET}}\right)$ can be estimated throughout radiation measurements in the L8 band ranges of visible and near infrared, together with weather data, acquired close to the orchard, and 

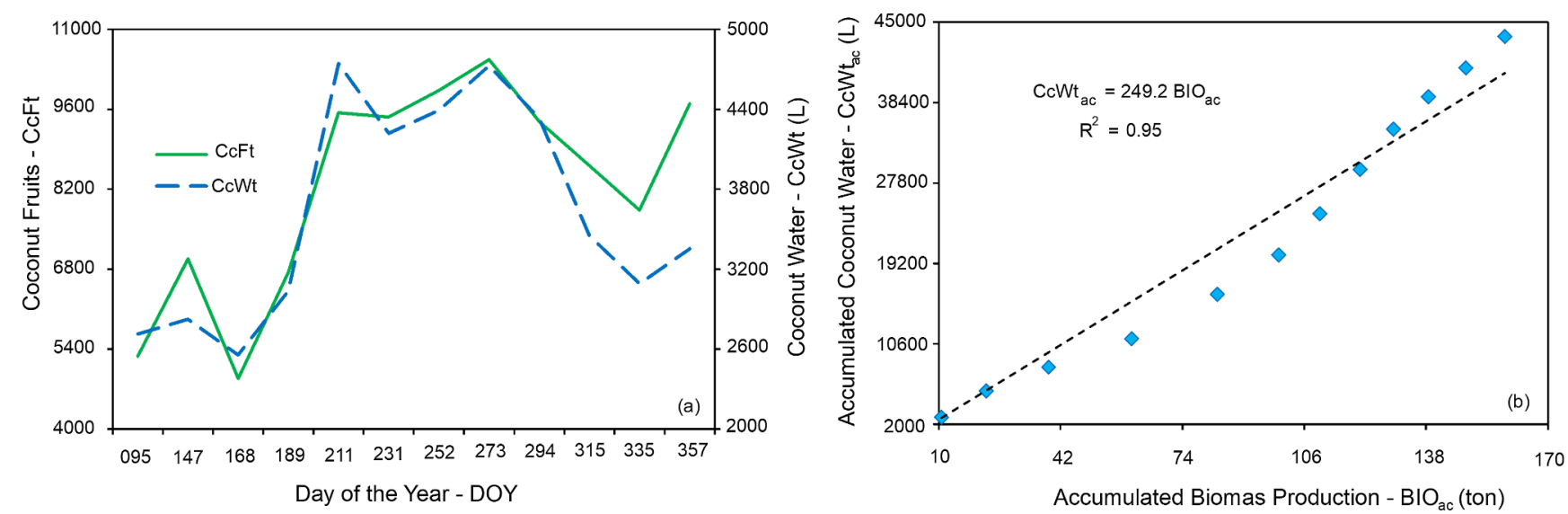

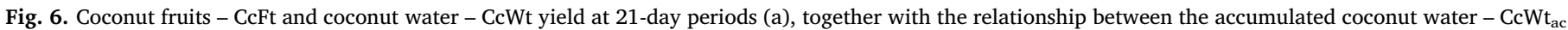
and accumulated biomass production $-\mathrm{BIO}_{\mathrm{ac}}$ (b), from April (DOY 095) to December (DOY 357), for A2 area (four-year-old palms).

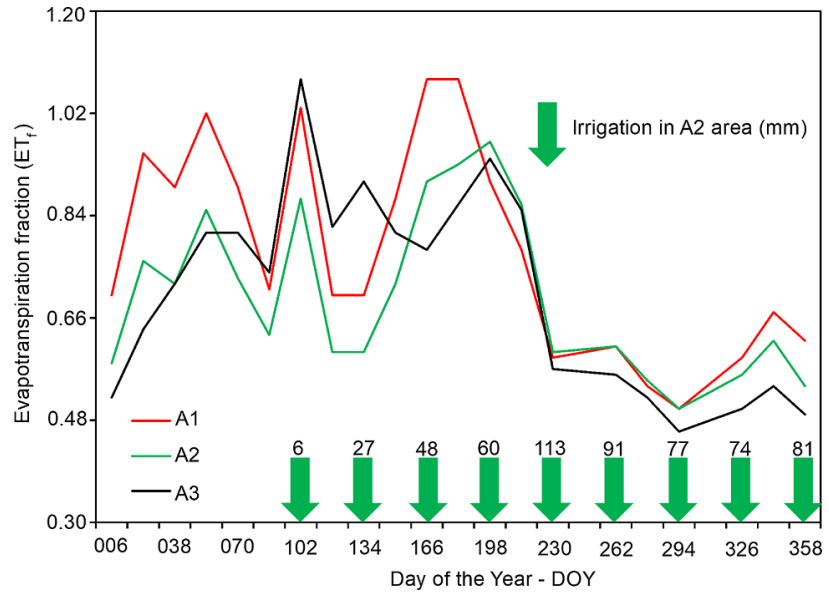

Fig. 7. Tendencies for the root-zone moisture index $\left(\mathrm{ET}_{\mathrm{f}}\right)$ in the dwarf coconut areas, with palms aging three (A1), four (A2), and five (A3) years. Green arrows show the 30-day accumulated irrigation $(\mathrm{mm})$ in the four-year-old palms inside A2 area. (For interpretation of the references to color in this figure legend, the reader is referred to the web version of this article.)

yield measurements.

Analyzing the root-zone moisture index, i.e. the fraction of actual ET to reference ET $\left(\mathrm{ET}_{0}\right)$, it was noticed expressive differences among its values, confronting the wettest and the driest periods, disregarding palm ages. The results evidenced the need for inter-row weed control throughout mulching, while conserving soil moisture during the climatically driest periods of the year.

The analyses carried out may contribute to rational crop and irrigation management for dwarf coconut, giving more confidence to the coupled applications of SAFER and RUE models to L8 images, together with agrometeorological data, under the coastal conditions of the Northeast Brazil. The modelling can be employed as a tool for management, agro-climatic zoning, and irrigation scheduling.

\section{Declaration of Competing Interest}

On behalf of all authors, the corresponding author states that there is no conflict of interest.

\section{Acknowledgements}

To Brazilian Agricultural Research Corporation (Embrapa), for the financial support to the research dealing with coconut irrigation in Northeast Brazil, project code: 12.15.01.001.00.00.

\section{Reference}

Allen, R.G., Pereira, L.S., Raes, D., Smith, M., 1998. Crop evapotranspiration. Guidelines for computing crop water requirements. FAO Irrigation and Drainage Paper 56 Rome, Italy, $300 \mathrm{pp}$.

de Almeida, C.T., Delgado, R.C., Galvão, L.S., Aragão, L.E.O.C., Ramos, M.C., 2018. Improvements of the MODIS Gross Primary Productivity model based on a comprehensive uncertainty assessment over the Brazilian Amazonia. ISPRS J. Photogramm. Remote Sens. 145, 268-283.

Azevedo, P.V., Sousa, I.F., Silva, B.B. da, Silva, V. de P.R., 2006. Water-use efficiency of dwarf-green coconut (Cocos nucifera L.) orchards in northeast Brazil. Agric. Water Manage. 84, 259-264.

Bastiaanssen, W.G.M., Ali, S., 2003. A new crop yield forecasting model based on satellite measurements applied across the Indus Basin, Pakistan. Agric. Ecosyst. Environ. 94 $321-340$.

Bhattarai, N., Wagle, P., Gowda, P.H., Kakani, V.G., 2017. Utility of remote sensing-based surface energy balance models to track water stress in rain-fed switchgrass under dry and wet conditions. ISPRS J. Photogramm. Remote Sens. 113, 128-141.

Carr, M.K.V., 2011. The water relations and irrigation requirements of coconut (cocos nucifera): a review. Exp. Agr. 47, 27-51.

Castelli, M., Asam, S., Jacob, A., Zebisch, M., Notarnicola, C., 2018. Monitoring daily evapotranspiration in the Alps exploiting Sentinel-2 and meteorological data. Remote Sens. Hydrol. Symp. (ICRS-IAHS).

Cintra, F.L.D., Resende, R.S., Leal, M.L.S., Portela, J.C., 2009. Efeito de volumes de água de irrigação no regime hídrico do solo coeso dos tabuleiros e na produção do coqueiro. Rev. Bras. Ci. Solo 33, 1041-1051.

De La Fuente-Sáiz, D., Ortega-Farias, S., Fonseca, D., Ortega-Salazar, S., Kilic, A., Allen, R.G., 2017. Calibration of METRIC model to estimate energy balance over a dripirrigated apple orchard. Remote Sens. 9, 1-18.

Folhes, M.T., Rennó, C.D., Soares, J.V., 2009. Remote sensing for irrigation water management in the semi-arid Northeast of Brazil. Agric. Water Manage. 96, 1398-1409.

Franco, R.A.M., Hernandez, F.B.T., Teixeira, A.H. de C., Leivas, J.F., Nuñez, D.N.C., Neale, C.M.U., 2016. Water productivity mapping using Landsat 8 satellite together with weather stations. Proc. SPIE 9998, 99981H-1-99981H-12.

Holtzman, M.E., Carmona, F., Rivas, R., Niclòs, R., 2018. Early assessment of crop yield from remotely sensed water stress and solar radiation data. ISPRS J. Photogramm. Remote Sens. 145, 297-306.

Jayakumar, M., Janapriya, S., Surendran, U., 2017. Effect of drip fertigation and polythene mulching on growth and productivity of coconut (Cocos nucifera L.), water, nutrient use efficiency and economic benefits. Agric. Water Manage. 182, 87-93.

Kelting, F.M.S., 2010. O Clima e a Paisagem da Bacia Hidrográfica do Litoral: Estado do Ceará. Bol. Goiano Geog. 29, 83-99.

Li, X., Zhang, X., Niu, J., Tong, L., Kang, S., Du, T., Li, S., Ding, R., 2016. Irrigation water productivity is more influenced by agronomic practice factors than by climatic factors in Hexi Corridor, Northwest China. Sci. Rep. 6, 1-10.

Madurapperuma, W.S., de Costa, W.A.J.M., Sangakkara, U.R., Jayescara, C., 2009. Estimation of water use of mature coconut (Cocos nucifera L.) cultivars (CRIC 60 and CRIC 65) grown in the low country intermediate zone using the compensation heat pulse method (CHPM). J. Natl. Sci. Found. Sri Lanka 37, 175-186.

Miranda, F.R., Montenegro, A.A.T., Lima, R.N., Rosseti, A.G., Freitas, J.A.D., 2004. Distribuição do sistema radicular de plantas jovens de coqueiro-anão sob diferentes frequências de irrigação. Rev. Cienc. Agron. 35, 309-318.

Miranda, F.R., Gomes, A.R.M., de Oliveira, C.H.C., Montenegro, A.A.T., Bezerra, F.M.L., 2007. Evapotranspiração e coeficientes de cultivo do coqueiro anão-verde na região litorânea do Ceará. Rev. Cienc. Agr. 38, 129-135.

Mokhtari, A., Noory, H., Pourshakouri, F., Haghighatmehr, P., Afrasiabian, Y., Razavi, M., Fereydooni, F., Naeni, A.S., 2019. Calculating potential evapotranspiration and single crop coefficient based on energy balance equation using Landsat 8 and Sentinel-2. ISPRS J. Photogramm. Remote Sens. 154, 231-245.

Molden, D., Frenken, K., Barker, R., de Fraiture, C., Bancy, M., Svendsen, M., Sadoff, C., 
Finlayson, C.M., 2007. Trends in water and agricultural development. Water for Food, Water for Life: A Comprehensive Assessment of Water Management in Agriculture. International Water Management Institute, London, Earthscan, Colombo.

Monteith, J.L., 1972. Solar radiation and productivity in tropical ecosystems. J. Appl. Ecol. 9, 747-766.

Moraes, J.O., Freire, G.S., Pinheiro, L.S., Souza, M.J.N., Carvalho, A.M., Pessoa, P.R.S., Oliveira, S.H.M., 2006. In: Erosão e Progradação no Litoral Brasileiro. MMA, Brasília, pp. 131-154.

Naresh Kumar, S., Kasturi Bai, K.V., Rajagopal, V., Aaggarwal, P.K., 2008. Simulating coconut growth, development and yield with the InfoCrop-coconut model. Tree Physiol. 28, 1049-1058.

Nuñez, D.C., Hernandez, F.B.T., Teixeira, A.H. de C., Franco, R.A.M., Leivas, J.F., 2017. Water productivity using SAFER - Simple Algorithm for Evapotranspiration Retrieving in watershed. Rev. Bras. Eng. Agr. Amb. 21, 524-529.

Ramírez-Cuesta, J.M., Allen, R.G., Zarco-Tejada, P.J., Kilic, A., Santos, C., Lorite, I.J., 2019. Impact of the spatial resolution on the energy balance components on an opencanopy olive orchard. Int. J. Appl. Earth Obs. Geoinf. 74, 88-102.

Resende, R.S., Santos, H.R., de Amorim, J.R.A., Souza, G., Meneses, T.N., 2015. Efeito da cobertura morta no padrão de distribuição da água em microaspersão. Ver. Bras. Agr. Irrig. 9, 278-286.

Roupsard, O., Bonnefond, J.M., Irvine, M., Berbigier, P., Nouvellon, Y., Dauzat, J., Taga, S., Hamel, O., Jourdan, C., Saint-André, L., Mialet-Serra, I., Labouisse, J.P., Epron, D., Joffre, R., Braconnier, S., Rouzière, A., Navarro, M., Bouillet, J.P., 2006. Partitioning energy and evapotranspiration above and below a tropical palm canopy. Agric. Forest. Meteorol. 139, 252-268.

Rozenstein, O., Haymann, N., Kaplan, G., Tanny, J., 2018. Estimating cotton water consumption using a time series of Sentinel-2 imagery. Agric. Water Manage. 207, 44-52.

Senay, G.B., Schauer, M., Friedrichs, M., Velpuri, N.M., Ramesh, K.S., 2017. Satellitebased water use dynamics using historical Landsat data (1984-2014) in the southwestern United States. Remote Sens. Environ. 202, 98-112.

Silva, B.B., Braga, A.C., Braga, C.C., de Oliveira, L.M.M., Galvíncio, J.D., Montenegro, S.M.G.L., 2012. Evapotranspiração e estimativa da água consumida em perímetro irrigado do semiárido brasileiro por sensoriamento remoto. Pesq. Agropec. Bras. 47, 1218-1226.

Silva, C.O.F., Manzione, R.L., Teixeira, A.H. de C., 2018a. Modelagem espacial da evapotranspiração e produtividade hídrica na porção paulista do afloramento do aquífero Guarani entre 2013 e 2015. Holos Env. 18, 126-140.

Silva, C.O.F., Manzione, R.L., Filho, J.L.A., 2018b. Large-Scale spatial modeling of crop coefficient and biomass production in agroecosystems in Southeast Brazil. Horticulturae 4, 1-20.

Singh, R.K., Senay, G.B., Velpuri, N.M., Bohms, S., Scott, R.L., Verdin, J.P., 2014. Actual evapotranspiration (water use) assessment of the Colorado River Basin at the Landsat resolution using the operational simplified surface energy balance model. Remote Sens. 6, 233-256.

Sousa, I.F., Netto, A.O.A., Campeche, L.F.M.S., Barros, A.C., da Silva, V.P.S., de Azevedo, P.V., 2011. Lisímetro de pesagem de grande porte. Parte II: Consumo hídrico do coqueiro anão verde irrigado. Rev. Bras. Agr. Eng. Agr. Amb. 15, 526-532.

Teixeira, A.H. de C., 2010. Determining regional actual evapotranspiration of irrigated and natural vegetation in the São Francisco river basin (Brazil) using remote sensing and Penman-Monteith equation. Remote Sens. 2, 1287-1319.

Teixeira, A.H. de C., Bastiaanssen, W.G.M., Ahmad, M-ud-D., Moura, M.S.B., Bos, M.G., 2008. Analysis of energy fluxes and vegetation-atmosphere parameters in irrigated and natural ecosystems of semi-arid Brazil. J. Hydrol. 362, 110-127.

Teixeira, A.H. de C., Bastiaanssen, W.G.M., Ahmad, M-ud-D., Bos, M.G., 2009. Reviewing SEBAL input parameters for assessing evapotranspiration and water productivity for the Low-Middle São Francisco River basin, Brazil Part B: application to the regional scale. Agric. Forest. Meteorol. 149, 477-490.

Teixeira, A.H. de C., Leivas, J.F., Silva, G.B., 2016. Options for using Landsat and RapidEye satellite images aiming the water productivity assessments in mixed agroecosystems. Proc. SPIE 9998, 99980A-1-99980A-11.

Teixeira, A.H. de C., Simão, F.R., Leivas, J.F., Gomide, R.L., Reis, J.B.R.S., Kobayashi, M.K., Oliveira, F.G., 2018. Water productivity modeling by remote sensing in the semiarid region of Minas Gerais State, Brazil. In: Arman, H., Yuksel, I. (Eds.), Arid Environments and Sustainability, 1st ed. InTec, London, pp. 94-108.

Vanino, S., Nino, P., Micheleb, C.D., Bolognesi, S.F., D'Urso, G., Bene, C.D., Pennelli, B., Vuolo, F., Farina, R., Pulighe, G., Napoli, R., 2018. Capability of Sentinel-2 data for estimating maximum evapotranspiration and irrigation requirements for tomato crop in Central Italy. Remote Sens. Environ. 215, 452-470.

Vanhellemont, Q., Ruddick, K., 2014. Turbid wakes associated with offshore wind turbines observed with Landsat 8. Remote Sens. Environ. 145, 105-115.

Wagle, P., Bhattarai, N., Gowda, P.H., Kakani, V.G., 2017. Performance of five surface energy balance models for estimating daily evapotranspiration in high biomass sorghum. ISPRS J. Photogramm. Remote Sens. 128, 192-203. 